\title{
Strategi Pengembangan Subsektor Peternakan dalam Rangka Memperkuat Sektor Pertanian di Kabupaten Boyolali
}

\author{
Nuning Setyowati \\ Jurusan Sosial Ekonomi Pertanian/Agrobisnis, Fakultas Pertanian, Universitas Sebelas Maret \\ Jl.Ir.Sutami No 36 A Surakarta 57126, E-mail: noenk_setyo@yahoo.com
}

\begin{abstract}
ABSTRAK
Penelitian ini bertujuan untuk mengidentifikasi posisi subsektor peternakan dalam kerangka pembangunan sektor pertanian di Kabupaten Boyolali. Lebih lanjut, penelitian ini juga bertujuan untuk merumuskan strategi pengembangan subsektor peternakan sebagai upaya meningkatkan kinerjanya. Penelitian ini merupakan penelitian deskriptif analitik dengan alat analisis yang digunakan adalah Tipologi Klassen dan analisis SWOT. Hasil penelitian menunjukkan bahwa subsektor peternakan merupakan subsektor potensial yang berarti subsektor ini mampu memberikan kontribusi yang lebih besar dibanding kontribusi PDRB Kabupaten Boyolali namun memiliki laju pertumbuhan yang lambat. Strategi pengembangan subsektor peternakan di kabupaten Boyolali antara lain: Peningkatan produksi komoditas peternakan dan produk olahannya, Penguatan agroindustri berbasis komoditas/produk peternakan, Penguatan permodalan bagi peternak dan agroindustri peternakan, Pengembangan usaha pemasaran untuk komoditi peternakan dan produk olahannya, Peningkatan peran KUD dan GKSI untuk mendukung kinerja subsektor peternakan dan Pengembangan inovasi pakan ternak.
\end{abstract}

Kata kunci: strategi pengembangan, subsektor peternakan, tipologi klassen, SWOT

\section{Development Strategy of Livestock Subsector to Strengthen Agricultural Sector In Boyolali}

\begin{abstract}
This study aims to identify the position of the livestock subsector within the framework of the agricultural sector development in the Boyolali District. Furthermore, this research also aims to formulate livestock sector development strategy as an effort to improve its performance. This study is a descriptive analytic with analysis tool used is the Typology Klassen and SWOT analysis. The results showed that the livestock subsector is a potential sub-sectors which means that this sub-sector contribution is greater than the GDP contribution Boyolali district but it has a slow growth rate. Livestock sector development strategy in Boyolali district as follow: Increased production of farm commodities and processed products, strengthening of agroindustry based commodity / farm products, strengthening of capital for farmers and agroindustry, marketing business development for farm commodities and processed products, increase the role of cooperatives and GKSI for support of livestock sub-sector performance and development of fodder innovation.
\end{abstract}

Key words: development strategy, livestock subsector, typology klassen, SWOT 


\section{PENDAHULUAN}

Sektor Pertanian di Kabupaten Boyolali ditopang oleh lima sub sektor pertanian pertanian yaitu Subsektor Tanaman Bahan Makanan, Sub sektor perkebunan rakyat, Subsektor Perikanan, Perkebunan dan Seb sektor Peternakan. Adapun Kelima subsektor pertanian memberikan kontribusi yang berbeda terhadap PDRB Kabupaten Boyolali. Besarnya kontribusi setiap subsektor pertanian dapat dilihat pada Tabel 1 .

Berdasarkan Tabel 1 dapat diketahui bahwa masing-masing subsektor pertanian di Kabupaten Boyolali memberikan kontribusi yang bervariasi. Kontribusi terbesar adalah subsektor Bahan Makanan yaitu sebesar Rp. 810.412.526,- dan yang paling kecil adalah subsektor kehutanan (Rp.13.984.395,-). Subsektor peternakan merupakan kontributor kedua setelah tanaman bahan makanan, sehingga peranannya layak untuk diperhatikan. Potensi geografis yang dimiliki mendorong berkembangnay subsektor peternakan didaerah ini. Kabupaten Boyolali selama ini dikenal dengan berbagai produk peternakan seperti susu dan abon daging sapi. Kinerja sektor pertanian di Kabupaten Boyolali disamping dilihat dari kontribusi terhadap PDRB, dapat dilihat juga dari laju pertumbuhannya. Adapun laju pertumbuhan subsektor pertanian di Kabupaten Boyolali tersaji di Tabel 2.

Tabel 2 menunjukkan bahwa laju pertumbuhan setiap subsektor pertanian sangat berfluktuatif. Laju subsektor perikanan merupakan subsektor yang paling tinggi dengan rata-rata laju pertumbuhan $26,29 \%$. Subsektor peternakan merupakan subsektor yang memiliki laju pertumbuhan paling kecil dengan rata-rata $0,03 \%$. Kondisi ini mengindikasikan diperlukannya upaya untuk menjaga konsistensi laju ataupun kontribusi subsektor peternakan.

Penelitian ini bertujuan untuk mengidentifikasi dan mengklasifikasikan subsektor pertanian (khususnya subsektor peternakan) menjadi empat klasifikasi yaitu Subsektor Prima, Subsektor Potensial, Subsektor Berkembang dan Subsektor
Terbelakang. Pengembangan sub sektor peternakan tidak hanya membutuhkan identifikasi posisinya semata. Lebih jauh lagi setelah dilakukan klasifikasi kemudian diperlukan perumusan strategi pengembangan subsektor peternakan sehingga diperoleh alternatif strategi pengembangan. Dengan demikian, upaya pemerintah daerah kabupaten Boyolali dalam mengembangkan subsektor peternakan menjadi lebih jelas dan terarah. Bertolak dari kebutuhan inilah kemudian penelitian ini menjadi penting untuk dilakukan.

Penelitian terdahulu mengenai klasifikasi subsektor pertanian telah banyak dilakukan, antara lain oleh Maseli (2010) yang dalam penelitiannya menemukan bahwa subsektor peternakan di Kabupaten Banjarnegara merupakan subsector prima yang artinya subsektor ini mampu memberikan kontribusi besar dan memiliki laju pertumbuhan positif. Adapun strategi pengembangan yang direkomendasikan untuk kemajuan subsektor peternakan antara lain melalui upaya diversifikasi produk hasil peternakan, stabilisasi harga hasil peternakan dan ssstem gaduh ternak.

Penelitian oleh Mualif (2010) menemukan bahwa subsector peternakan di Kotamadya Salatiga merupakan subsektor potensial yang artinya adalah subsector peternakan mampu memberikan kontribusi besar namun memiliki laju pertumbuhan yang lambat. Strategi pengembangan yang ditawarkan melalui penelitian ini antara lain melalui peningkatan produksi, penerapan teknologi peternakan, peningkatan pemasaran hasil peternakan dan aktivasi penyuluhan dan pendampingan peternak. Penelitian-penelitian di atas dijadikan referensi dalam penelitian ini dengan alasan adanya kesamaan alat analisis penelitian, yaitu Tipologi Klassen.

Menurut Widodo (2006:120-122) teknik Tipologi Klassen dapat digunakan untuk mengetahui gambaran tentang pola dan struktur pertumbuhan sektoral daerah. Analisis ini mendasarkan pengelompokkan suatu sektor dengan melihat pertumbuhan dan kontribusi sektor tertentu terhadap total PDRB suatu daerah. Dengan menggunakan analisis 
Tabel 1. Produk Domestik Regional Bruto Subsektor Pertanian Kabupaten Boyolali Tahun 2004$8(\mathrm{Rp})$

\begin{tabular}{|c|c|c|c|c|c|c|}
\hline \multirow{2}{*}{ Sub Sektor } & \multicolumn{5}{|c|}{ Tahun } & \multirow{2}{*}{ Rata rata } \\
\hline & 2004 & 2005 & 2006 & 2007 & 2008 & \\
\hline Bahan & 738.392 .861 & 800.110 .779 & 824.911 .068 & 835.810 .122 & 852.837 .802 & 810.412 .526 \\
\hline Makanan & & & & & & \\
\hline $\begin{array}{l}\text { Perkebunan } \\
\text { Rakyat }\end{array}$ & 85.594 .617 & 83.448 .733 & 76.149 .993 & 74.189 .400 & 66.755 .210 & 77.227.591 \\
\hline Peternakan & 365.582 .889 & 361.141 .338 & 358.162 .382 & 363.540 .722 & 365.933 .990 & 362.872.264 \\
\hline Kehutanan & 12.963 .435 & 13.888 .414 & 14.248 .486 & 14.325 .013 & 14.496 .626 & 13.984.395 \\
\hline Perikanan & 12.255 .423 & 12.011 .516 & 17.200 .249 & 17.965 .543 & 28.659 .398 & 17.618.426 \\
\hline PDRB & 1.214 .789 .225 & 1.270 .600 .780 & 1.290 .672 .178 & 1.305 .830 .800 & 1.328 .683 .026 & 1.282 .115 .202 \\
\hline
\end{tabular}

Sumber: Boyolali Dalam Angka 2008

Tabel 2. Laju Pertumbuhan Subsektor Pertanian Kabupaten Boyolali Tahun 2004-8

\begin{tabular}{lrrrrr}
\hline \multirow{2}{*}{\multicolumn{1}{c}{ Subsektor Pertanian }} & \multicolumn{4}{c}{ Tahun } & Rata-rata \\
\cline { 2 - 5 } & 2005 & 2006 & 2007 & 2008 & $\mathbf{3 , 7 0}$ \\
\hline Bahan Makanan & 8,36 & 3,10 & 1,32 & 2,04 & $\mathbf{- 5 , 9 6}$ \\
Perkebunan Rakyat & $-2,51$ & $-8,75$ & $-2,57$ & $-10,02$ & $\mathbf{0 , 0 3}$ \\
Peternakan & $-1,21$ & $-0,82$ & 1,50 & 0,66 & $\mathbf{2 , 8 6}$ \\
Kehutanan & 7,13 & 2,59 & 0,54 & 1,19 & $\mathbf{2 6 , 2 9}$ \\
Perikanan & $-1,99$ & 43,19 & 4,45 & 59,52 & $\mathbf{2 , 2 7}$ \\
Laju pertumbuhan PDRB Total & 4,59 & 1,58 & 1,17 & 1,75 & \\
\hline
\end{tabular}

Sumber: Analisis Data Sekunder

Tipologi Klassen, suatu sektor dapat dikelompokkan ke dalam 4 kategori, yaitu: sektor prima,sektor potensial, sektor berkembang, dan sektor terbelakang.

Analisis SWOT adalah identifikasi berbagai faktor secara sistematis untuk merumuskan strategi perusahaan. Analisis ini didasarkan pada logika yang dapat memaksimalkan kekuatan (Strengths) dan peluang (Opportunities), namun secara bersamaan dapat meminimalkan kelemahan (Weaknesses) dan ancaman (Threats). Proses pengambilan keputusan strategis selalu berkaitan dengan pengembangan misi, tujuan, strategi, dan kebijakan perusahaan. Dengan demikian perencana strategis (strategic planner) harus menganalisis faktor-faktor strategis (kekuatan, kelemahan, peluang, dan ancaman) dalam kondisi yang ada saat ini (Rangkuti, 2001).

\section{MATERI DAN METODE}

Metode dasar penelitian yang digunakan dalam penelitian ini adalah metode deskriptif analitik, dimana data yang dikumpulkan mula-mula disusun, dijelaskan dan kemudian dianalisis karena itu metode ini sering disebut metode analitik (Surakhmad, 1998). Data yang digunakan berupa data Produk Domestik Regional Bruto (PDRB Kabupaten Boyolali dan PDRB Jawa Tengah tahun 2004-2008 ADHK 2000, Data Rencana Pembangunan Jangka Menengah Daerah (RPJMD) Kabupaten Boyolali dan data lain yang mendukung tujuan penelitian ini. Data primer berupa wawancara intensif dengan stake holder yang berkompeten terkait dengan perumusan strategi pengembangan sektor peternakan. Stakeholder tersebut antara lain : BAPPEDA, Kepala Dinas Peternakan dan 
Perikanan, Peternak dan Akademisi. Wawancara dilakukan untuk menggali berbagai permasalahan terkait dengan subsektor peternakan yang ada sehingga diperoleh faktor strategis (kekuatan, kelemahan, peluang, ancaman). Faktor strategis tersebut kemudian akan ditindak lanjuti dengan analisis SWOT.

\section{Analisis Data}

Penentuan klasifikasi subsektor pertanian (termasuk subsektor peternakan) di Kabupaten Boyolali dapat diketahui dengan menggunakan pendekatan Tipologi Klassen. Tipologi Klassen merupakan alat analisis yang dapat digunakan untuk mengidentifikasi sektor, subsektor, usaha atau komoditi unggulan di suatu daerah (Widodo, 2006)

\section{Klasifikasi Subsektor Pertanian di Kabupaten Boyolali}

Analisis Tipologi Klassen dalam klasifikasi subsektor pertanian di Kabupaten Boyolali membandingkan pertumbuhan subsektor pertanian di Kabupaten Boyolali dengan pertumbuhan PDRB Kabupaten Boyolali dan membandingkan kontribusi subsektor pertanian dengan kontribusi PDRB Kabupaten Boyolali. Pengklasifikasian subsektor pertanian di Kabupaten Boyolali dapat dilihat pada Tabel 3.

\section{Analisis Strategi Pengembangan Subsektor Peternakan}

Setelah dilakukan klasifikasi pada subsektor peternakan maka akan dapat dirumuskan suatu strategi pengembangan dalam rangka perencanaan pembangunan ekonomi daerah untuk meningkatkan pendapatan daerah Kabupaten Boyolali.

Matriks

Threats-OpportunitiesWeaknesses-Strengths (TOWS) merupakan matching tool yang penting untuk membantu mengembangkan empat tipe strategi. Keempat tipe strategi yang dimaksud adalah :1) Strategi SO (Strength-Opportunity). Strategi ini menggunakan kekuatan internal subsektor peternakan untuk meraih peluang yang ada di lingkungan eksternal. 2) Strategi WO
(Weakness-Opportunity). Strategi ini bertujuan untuk memperkecil kelemahan internal subsektor peternakan dengan memanfaatkan peluang eksternal. 3) Strategi ST (StrengthThreat). Strategi ST digunakan subsektor peternakan untuk menghindari atau mengurangi dampak dari ancaman ekternal. 4) Strategi WT (Weakness-Threat). Strategi ini merupakan taktik untuk bertahan dengan cara mengurangi kelemahan internal serta menghindari ancaman. Adapun Matrik SWOT tersaji pada Tabel 4 .

\section{HASIL DAN PEMBAHASAN}

\section{Klasifikasi Subsektor Pertanian}

Hasil dari analisis Tipologi Klassen ini menunjukkan posisi pertumbuhan dan kontribusi subsektor di Kabupaten Boyolali. Berdasarkan Matriks Tipologi Klassen, subsektor pertanian di Kabupaten Boyolali dapat diklasifikasikan menjadi tiga kategori, yaitu sektor potensial, sektor berkembang, dan sektor terbelakang seperti terlihat pada Tabel 5.

Berdasarkan hasil Tipologi Klassen, subsektor yang termasuk dalam subsektor potensial yaitu subsektor tanaman bahan makanan dan subsektor peternakan. Subsektor pertanian di Kabupaten Boyolali yang termasuk kategori sektor berkembang yaitu subsektor perikanan. Subsektor pertanian yang termasuk kategori subsektor terbelakang yaitu subsektor tanaman perkebunan dan kehutanan.

Subsektor peternakan sebagai subsektor potensial memiliki kontribusi yang lebih besar dibandingkan dengan kontribusi PDRB Kabupaten Boyolali. Subsektor peternakan memiliki kontribusi yang besar namun laju pertumbuhannya lambat. Hasil produksi seperti ternak seperti sapi merupakan hasil produksi terbesar diantara produksi ternak lain di Kabupaten Boyolali. Hasil dari berbagai komoditi subsektor peternakan di Kabupaten Boyolali ini diharapkan dapat memenuhi kebutuhan protein hewani penduduk daerah maupun luar daerah Kabupaten Boyolali serta dapat menghasilkan pendapatan bagi penduduk sehingga kesejahteraan penduduk dapat lebih meningkat. Saat ini sudah terdapat 
Tabel 3. Matriks Tipologi Klassen Subektor Pertanian di Kabupaten Boyolali

\begin{tabular}{|c|c|c|}
\hline Laju $\begin{array}{c}\text { Kertumbuhan } \\
\text { sektoral }\end{array}$ & $\begin{array}{l}\text { Kontribusi besar (kontribusi } \\
\text { PDRB }_{\text {subsektor }} \geq \text { kontribusi } \\
\text { PDRB Kabupaten Boyolali }\end{array}$ & $\begin{array}{l}\text { Kontribusi kecil (kontribusi } \\
\text { PDRB }_{\text {subsektor }}<\text { kontribusi } \\
\text { PDRB Kabupaten Boyolali }\end{array}$ \\
\hline Tumbuh cepat $\left(\mathrm{r}_{\text {subsektor }} \geq \mathrm{r}_{\mathrm{PDRB}}\right)$ & Subsektor prima & Subsektor berkembang \\
\hline $\begin{array}{l}\text { Tumbuh lambat }\left(\mathrm{r}_{\text {subsektor }}<\right. \\
\left.\mathrm{r}_{\text {PDRB }}\right)\end{array}$ & Subsektor potensial & Subsektor terbelakang \\
\hline
\end{tabular}

Keterangan :

$\mathrm{r}_{\text {subsektor }}$ : laju pertumbuhan subsektor ke $\mathrm{i}$

$\mathrm{r}_{\mathrm{PDRB}} \quad$ : laju pertumbuhan PDRB Kabupaten Boyolali

Tabel 4. Matriks SWOT

\begin{tabular}{|c|c|c|}
\hline & $\begin{array}{c}\text { STRENGTH (S) } \\
\text { Tentukan 1-10 faktor-faktor } \\
\text { kekuatan internal }\end{array}$ & $\begin{array}{c}\text { WEAKNESS (W) } \\
\text { Tentukan 1-10 faktor-faktor } \\
\text { kekuatan internal }\end{array}$ \\
\hline $\begin{array}{c}\text { OPPURTINITIES (O) } \\
\text { Tentukan 1-10 faktor- } \\
\text { faktor } \\
\text { Peluang lingkungan }\end{array}$ & $\begin{array}{c}\text { STRATEGI S-O } \\
\text { Ciptakan strategi yang } \\
\text { menggunakan kekuatan untuk } \\
\text { memanfaatkan peluang }\end{array}$ & $\begin{array}{c}\text { STRATEGI W-O } \\
\text { Ciptakan strategi yang } \\
\text { meminimalkan kelemahan untuk } \\
\text { memanfaatkan peluang }\end{array}$ \\
\hline $\begin{array}{c}\text { THREATS (T) } \\
\text { Tentukan 1-10 faktor- } \\
\text { faktor } \\
\text { Peluang lingkungan }\end{array}$ & $\begin{array}{c}\text { STRATEGI S-T } \\
\text { Ciptakan strategi yang } \\
\text { menggunakan kekuatan untuk } \\
\text { mengatasi ancaman }\end{array}$ & $\begin{array}{c}\text { STRATEGI W-O } \\
\text { Ciptakan strategi yang } \\
\text { meminimalkan kelemahan untuk } \\
\text { menghindari ancaman }\end{array}$ \\
\hline
\end{tabular}

Sumber : Rangkuti, 2001

Tabel 5. Matriks Tipologi Klassen Subsektor Pertanian di Kabupaten Boyolali

\begin{tabular}{|l|l|l|}
\hline $\begin{array}{l}\text { Kontribusi } \\
\text { Sektoral } \\
\begin{array}{l}\text { Laju } \\
\text { Pertumbuhan Sektoral }\end{array}\end{array}$ & $\begin{array}{l}\text { Kontribusi Besar } \\
\text { Kontribusi PDRB } \\
\text { Kontriusi PDRB) }\end{array}$ & $\begin{array}{l}\text { Kontribusi Kecil } \\
\text { Kontribusi PDRB } \\
<\text { Kontribusi PDRB) }\end{array}$ \\
\hline $\begin{array}{l}\text { Tumbuh Cepat } \\
\left(\mathrm{r}_{\text {Sub sektor }} \geq \mathrm{r}_{\text {PDRB }}\right)\end{array}$ & $\begin{array}{l}\text { Subsektor Prima: } \\
-\end{array}$ & $\begin{array}{l}\text { Subsektor Berkembang: } \\
\text { Perikanan }\end{array}$ \\
\hline $\begin{array}{l}\text { Tumbuh Lambat } \\
\left(\mathrm{r}_{\text {Sub sektor }}<\mathrm{r}_{\text {PDRB }}\right)\end{array}$ & $\begin{array}{l}\text { Subsektor Potensial: } \\
\text { Bahan Makanan, } \\
\text { Peternakan }\end{array}$ & $\begin{array}{l}\text { Subsektor Terbelakang: } \\
\text { Tanaman Perkebunan, } \\
\text { Kehutanan }\end{array}$ \\
\hline
\end{tabular}

Sumber: Analisis Data Sekunder 
Rumah Pemotongan Hewan, namun masih dijumpai pemotongan sapi yang dilakukan di luar Rumah Pemotongan Hewan $(\mathrm{RPH})$. Hal ini disebabkan adanya kesadaran pelaku usaha sapi potong yang masih cukup rendah akan pentingnya kesehatan daging sehingga ada kendala dalam pengawasan kesehatan daging yang dapat dikonsumsi oleh masyarakat.

\section{Strategi Pengembangan Subsektor Peternakan}

Hasil analisis SWOT untuk subsektor peternakan secara ringkas tersaji dalam matrik pada Tabel 6.

Secara rinci, alternatif strategi pengembangan susbektor peternakan adalah sebagai berikut:

a. Peningkatan produksi komoditas peternakan dan produk olahannya

$$
\text { Salah satu komoditas }
$$

peternakan Kabupaten Boyolali adalah Sapi Perah dengan produknya yaitu susu. Produk susu dari Kabupaten Boyolali telah dikenal masyarakat luas. Paling tidak ada 6 Kecamatan penghasil susu antara lain Mojosongo, Musuk, Ampel, Selo, Boyolali dan Cepogo dengan sentra utamanya adalah Mojosongo dengan produksi susu 12.420.000 liter pada tahun 2008 . Produksi ini walaupun tinggi namun menurun jika dibandingkan tahun-tahun sebelumnya yang sampai mencapai 46.071.770 liter pada tahun 2004 . kendala yang dihadapi antara lain pasokan pakan yang kurang pada saat kemarau menjadi ancaman tersendiri bagi peternak. Bahkan tidak jarang, peternak harus mencari pakan ternak di Kabupaten lain seperti Klaten dan Sukoharjo. Selain itu, kualitas indukan lokal yang kurang bagus juga menyebabkan sapi perah yang dihasilkan juga tidak bagus. Pemerintah daerah hendaknya memperhatikan kelemahan-kelemahan ini. Sebagai contoh, dengan memberikan subsidi indukan sapi impor seperti jenis Freez
Holand dan New Zealand yang berkualitas baik sehingga diharapkan akan menghasilkan keturunan yang berkualitas baik.

b. Penguatan agroindustri berbasis komoditas/produk peternakan

Produk susu di Kabupaten Boyolali selama ini disalurkan ke pabrik susu yaitu Frisian Flag (Semarang) melalui KUD dan GKSI. Produk olahan susu antara lain yogurt dan kerupuk susu sudah diusahakan di Kabupaten Boyolali. Tidak hanya produk olahan susu, produk olahan berbahan baku produk peternakan lainnya seperti daging sapi juga telah dikembangkan seperti abon sapi (PT Diamond) yang bekerjasama dengan Indofood dan beberapa produk lainnya seperti keripik paru dan dendeng juga banyak diusahakan. Paling tidak ada 20 industri pengolahan daging. Agroindustri ini perlu penguatan karena memiliki potensi untuk dikembangkan. Suplai bahan baku yang kontinyu dan mudah menjadi keunggulan tersendiri untuk agroindustri berbahan baku daging dan susu di kabupaten Boyolali. Upaya yang dapat dilakukan misalnya melalui penyuluhan, pelatihan dan pendampingan UKM serta pembentukan kelompok usaha bersama sehingga keberadaan agroindustri ini menjadi semakin kuat.

c. Penguatan permodalan bagi peternak dan agroindustri peternakan

Salah satu kendalan yang dihadapi peternak antara lain adalah lemahnya modal. Apalagi untuk usaha ternak sapi yang membutuhkan modal cukup tinggi yaitu minimal 8 juta untuk membeli indukan sapi perah. Hal inilah yang menyebabkan skala usaha ternak sapi perah rakyat masih relatif kecil dengan kepemilikan sapi perah antara 23 ekor per rumah tangga. Bantuan modal dari pemerintah belum dirasakan dan kalaupun ada pendistribusiannya masih belum merata. Demikian halnya untuk agroindustri berbahan baku produk peternakan juga menghadapi kendala 
Tabel 6 . Alternatif Strategi Matriks SWOT Pengembangan Subsektor Peternakan

\begin{tabular}{|c|c|c|}
\hline Eksternal & $\begin{array}{l}\text { Kekuatan-S } \\
\text { 1) } \begin{array}{l}\text { Aparat teknis aktif memberikan } \\
\text { penyuluhan }\end{array} \\
\text { 2) } \begin{array}{l}\text { Peternak memiliki motivasi } \\
\text { tinggi }\end{array} \\
\text { 3) Penguasaan teknis berternak } \\
\text { sudah baik } \\
\text { 4) Manajemen usaha ternak sudah } \\
\text { baik (ada orientasi profit) } \\
\text { 5) Kualias produk berani bersaing } \\
\text { dengan wilayah lain } \\
\text { 6) } \begin{array}{l}\text { Inseminasi buatan sudah banyak } \\
\text { diakses oleh peternak }\end{array} \\
\text { 7) Peternak sudah mencoba } \\
\text { Mengembangkan industri } \\
\text { pengolahan } \\
\text { 8) Petani aktif diKUD dan GKSI }\end{array}$ & $\begin{array}{l}\text { Kelemahan-W } \\
\text { 1) Ketersediaan pakan hijauan } \\
\text { terkadang sulit diperoleh } \\
\text { 2) Usaha ternak sebagian besar } \\
\text { masih skala kecil } \\
\text { 3) Sumber daya modal peternak } \\
\text { relative rendah } \\
\text { 3) Kegagalan program Inseminasi } \\
\text { Buatan masih sangat tinggi } \\
\text { 4) Penguasaan teknologi di tingkat } \\
\text { peternak yang masih rendah } \\
\text { 5) Masih sempitnya cakupan } \\
\text { pemasaran produk peternakan } \\
\text { 6) Pengolahan produk peternakan } \\
\text { umumnya masih dilakukan } \\
\text { oleh pihak industri, bukan peternak }\end{array}$ \\
\hline $\begin{array}{l}\text { Peluang-O } \\
\text { 1) Infrastruktur menunjang } \\
\text { pengembangan produk } \\
\text { peternakan } \\
\text { 2) Adanya bantuan permodalan } \\
\text { dari pemerintah } \\
\text { 3) Masih terbukanya pasar } \\
\text { produk peternakan } \\
\text { 4) Tingginya inovasi produk } \\
\text { olahan peternakan } \\
\text { 5) Potensi wilayah mendukung } \\
\text { untuk pengembangan produk } \\
\text { peternakan } \\
\text { 6) Berkembangnya teknologi } \\
\text { informasi } \\
\text { 7) Perkembangan harga produk } \\
\text { peternakan semakin baik } \\
\end{array}$ & \begin{tabular}{l}
\multicolumn{1}{c}{ Strategi S-O } \\
1. Peningkatan produksi komoditas \\
peternakan dan produk olahannya \\
(S3,S4,S5,O3,)O5) \\
2. Penguatan agroindustri berbasis \\
komoditas/produk peternakan \\
(S5,S7,S8,O6,O4)
\end{tabular} & $\begin{array}{l}\text { Strategi W-O } \\
\text { 2. Penguatan permodalan bagi } \\
\text { peternak dan agroindustri } \\
\text { 3. Pengembangan usaha pemasaran } \\
\text { untuk komoditi peternakan dan } \\
\text { produk olahannya } \\
(\mathrm{W} 6, \mathrm{~W} 5, \mathrm{O} 3, \mathrm{O} 6, \mathrm{O} 7)\end{array}$ \\
\hline $\begin{array}{l}\text { Ancaman-T } \\
\text { 1) Resiko produk peternakan } \\
\text { cukup tinggi } \\
\text { 2) Semakin berkembangnya } \\
\text { industri pengolahan produk } \\
\text { peternakan } \\
\text { 3) Resiko keamanan produk } \\
\text { peternakan khususnya bagi } \\
\text { peternak kecil } \\
\text { 4) Virus/ penyakit yang } \\
\text { menyerang secara mewabah } \\
\text { dan mendadak } \\
\text { 5) Produktifitas yang belum } \\
\text { stabil dan kalah dengan } \\
\text { wilayah lain }\end{array}$ & $\begin{array}{l}\text { Strategi S-T } \\
\text { 1. Peningkatan peran KUD dan GKSI } \\
\text { untuk mendukung kinerja } \\
\text { subsektor peternakan } \\
(\mathrm{S} 8, \mathrm{~S} 5, \mathrm{~S} 3, \mathrm{~S} 1, \mathrm{~T} 5, \mathrm{~S} 2)\end{array}$ & $\begin{array}{l}\text { Strategi W-T } \\
\text { 1. Perbaikan kualitas ternak melalui } \\
\text { peningkatan kesehatan ternak } \\
\text { (S1,S3,S6,W4,W5) } \\
\text { 2. Pengembangan inovasi pakan } \\
\text { ternak (W1,W2,W5,T4,T5) }\end{array}$ \\
\hline
\end{tabular}

Sumber: Diolah Dari Data Primer 
terkait permodalan. Apalagi agroindustri ini juga menuntut modal yang cukup besar mengingat bahan baku yang digunakan adalah daging dan susu. Jika akses permodalan mudah dan ada penguatan modal dari pemerintah diharapkan peternak dan pelaku agroindustri akan semakin termotivasi untuk berkinerja. Penguatan peran KUD dan GKSI perlu dilakukan karena dua lembaga ini merupakantangan panjang penyaluran kredit dari pemerintah. Mekanisme pemberian kredit cukup mudah dan meringankan karena untuk pengembalian kredit dari peternak akan dipotong langsung dari susu yang disetorkan ke KUD atau GKSI. Penguatan modal juga perlu dilakukan bagi pelaku agroindustri dibidang peternakan seperti agroindustri susu dan daging sapi melalui bantuan kredit. Dengan penguatan modal ini, diharapkan peternak dan pelaku industri akan semakin termotivasi untuk meningkatkan kinerja.

a. Pengembangan usaha pemasaran untuk komoditi peternakan dan produk olahannya.

Produksi komoditi peternakan dan olahan yang tinggi tidak akan memberikan kontribusi yang berarti jika tidak diimbangi dengan pangsa pasar yang luas. Produk olahan seperti yogurt, kerupuk susu, abon daging sapi, dendeng dan kerupuk kulit sapi yang ada selama ini hanya dipasarkan diwilayah lokal dan sekitarnya. Belum ada kerjasama dengan pihak swasta atau industri untuk mendukung pemasarannya. Selama ini baru untuk pemasaran abon daging sapi yang sudah mulai bekerjasama dengan sektor industri (swasta) yaitu PT.Indofood untuk pemasarannya. Untuk produk lainnya umumnya dijual melalui toko oleh-oleh, pedagang perantara maupun dijual langsung ke konsumen. Produkproduk tersebut sangat prospektif mengingat produk tersebut merupakan makanan yang relatif tahan lama dan cocok sebagai makanan oleh-oleh. Upaya pengembangan pemasaran yang dapat dilakukan antara lain melalui kerjasama dengan supermarket (swalayan) dan pemasaran menggunakan internet ( $e$ commerce ) yang diharapkan mampu memperluas pangsa pasar.

b. Peningkatan peran KUD dan GKSI untuk mendukung kinerja subsektor peternakan.

KUD dan GKSI (Gabungan Koperasi Susu Indonesia) memegang peran penting dalam mata rantai pemasaran komoditi ataupun produk peternakan. KUD dan GKSI merupakan perantara antara peternak dan industri. Salah satu KUD yang aktif dalam membantu pemasaran produk peternakan adalah KUD Mojosongo. KUD ini secara aktif emnampung susu dari peternak sapi perah khususnya di Kecamatan Mojosongo. Penampungan dilakukan 2 kali yaitu pagi jam 05.30 dan sore hari jam 15.30. Produksi susu rata-rata per hari antara 8-10 liter dengan tingkat harga berkisar 2.5003.000 rupiah. Tanpa keberadaan KUD maupun GKSI peternak akan kesulitan untuk memasarkan produknya. Sisa produk susu sebagian dijual ke pedagang susu segar di pasar tradisional dan pedagang kaki lima diwilayah Boyolali, Klaten dan Surakarta. Mengingat pentingnya peran KUD dan GKSI ini maka diperlukan upaya peningkatan kinerja KUD dan GKSI melalui peningkatan jumlah dan kualitas SDM yang bekerja di KUD dan GKSI. Upaya yang dapat dilakukan misalnya melalui pelatihan manajemen usaha, quality control dan lain-lain.

c. Perbaikan kualitas ternak melalui peningkatan kesehatan ternak

Kesehatan ternak menjadi salah stu faktor penting dalan usaha ternak. Ternak sapi perah misalnya, kesehatan sapi akan menentukan produktifitas susu yang dihasilkan. Kendala terkait dengan kesehatan ternak antara lain adalah 
penyakit kembung yang sering menyerang sapi hingga menyebabkan kematian. Penyakit ini biasanya muncul pada musim pancaroba (pergantian musim). Sebenarnya pemerintah daerah telah memberikan layanan kesehatan setiap 70 hari sekali yang difasilitasi oleh Dinas peternakan. Layanan ini berupa periksa kebuntingan ternak dan cek kesehatan. Namun, terkadang peternak enggan membawa ternaknya ke posko pemeriksaan jika tidak ada keluhan/ gejala gangguan kesehatan pada ternaknya. Upaya yang dapat dilakukan adalah dengan memberikan penyuluhan dan pendampingan terkait pentingnya pemeliharaan kesehatan ternak secara intensif.

d. Pengembangan inovasi pakan ternak Pakan ternak disatu sisi merupakan kelebihan namun disisi lain juga berpeluang menjadi ancaman bagi peternak khususnya kambing, sapi dan domba. Pada musim penghujan pakan ternak (rumput) melimpah, namun dimusim kemarau ketersediaan rumput menipis dan peternak harus mencari rumput keluar daerah bahkan keluar kabupaten. Walaupun selain rumput juga tersedia pakan seperti bread ( dedak gandum) dan sentrat, namun harganya cukup mahal. Untuk bread (dedak gandum) harganya Rp.102.000,- per karung $(50 \mathrm{~kg})$ dan sentrat berkisar Rp.7500-10.000,- /Kg. Hal ini menjadi kendala bagi petani. Oleh karena itu, diperlukan inovasi baru dalam penciptaan pakan ternak yang mampu memenuhi kebutuhan ternak namun tidak memerlukan biaya yang tinggi. Contohnya adalah melalui fermentasi hijauan dan konsentrat.

\section{KESIMPULAN}

1. Berdasarkan Tipologi Klassen, subsektor peternakan merupakan subsektor potensial yaitu subsektor yang memiliki kontribusi besar terhadap PDRB Kabupaten Boyolali namun memiliki laju pertumbuhan yang relatif lambat.

2. Strategi pengembangan subsektor Peternakan antara lain:

a. Peningkatan produksi komoditas peternakan dan produk olahannya

b. Penguatan agroindustri berbasis komoditas/produk peternakan

c. Penguatan permodalan bagi peternak dan agroindustri peternakan

d. Pengembangan usaha pemasaran untuk komoditi peternakan dan produk olahannya

e. Peningkatan peran KUD dan GKSI untuk mendukung kinerja subsektor peternakan

f. Perbaikan kualitas ternak melalui peningkatan kesehatan ternak

g. Pengembangan inovasi pakan ternak

\section{DAFTAR PUSTAKA}

BPS.2008. Kabupaten Boyolali dalam Angka 2008. Badan Pusat Statistik Kabupaten Boyolali. Boyolali.

David,F.R.2002. Manajemen Strategis, Versi Bahasa Indoensia. Edisi ketujuh.PT.Prenhallindo. Jakarta

Julianti, DM.2010. Strategi Pengembangan Sektor Pertanian di Kabupaten Banjarnegara (Pendekatan Tipologi Klassen). Skripsi Fakultas Pertanian Universitas Sebelas Maret. .Tidak dipublikasikan.

Mualif, E.2010. Pengembangan Sektor Pertanian di Kota Salatiga Dengan pendekatan Tipologi Klassen. Skripsi Fakultas Pertanian Universitas Sebelas Maret. .Tidak dipublikasikan.

Rangkuti, F.2001. Analisis SWOT Teknik Membedah Kasus Bisnis. PT.Gramedia Pustaka Utama. Jakarta.

Surakhmad, W. 1998. Pengantar Penelitian Ilmiah: Dasar, Metode, dan Teknik. Penerbit Tarsito. Bandung.

Umar, Husein. 2002. Strategic Management In Action. Gramedia Pustaka Utama. Jakarta

Widodo, T. 2006. Perencanaan Pembangunan: Aplikasi Komputer (Era Otonomi Daerah). UPP STIM YKPN. Yogyakarta. 